\title{
Molecular markers for early detection of cervical neoplasia
}

\author{
Elizabeth R. Unger*, Martin Steinau, Mangalathu S. Rajeevan, David Swan, Daisy R. Lee and \\ Suzanne D. Vernon \\ Viral Exanthems and Herpesvirus Branch, Division of Viral and Rickettsial Diseases, National Center for \\ Infectious Diseases, Centers for Disease Control and Prevention, Public Health Service, US Department of Health \\ and Human Services, Atlanta, GA, USA
}

\section{Introduction}

In the United States, cervical cancer screening programs based on exfoliated cervical cytology (Pap smears) have significantly reduced the incidence of invasive cervical cancer. As a result of this success, current cervical cancer screening programs in the US are not directed at invasive disease, but at detection of the precursors of carcinoma, referred to as dysplasias, squamous intraepithelial lesions (SIL) or cervical intraepithelial neoplasias (CIN). The progressive histologic and cytologic changes that occur during the multistep process of cervical carcinogenesis can be divided into multiple stages, early lesions known as CIN 1 or LSIL and high grade lesions known as CIN 2, 3 or HSIL. The natural history of these cervical cancer precursor lesions is difficult to study because they are usually biopsied or otherwise treated as soon as detected. However, it is clear that CIN 1 and 2 lesions are more likely to regress than to progress to invasive disease [37, 69]. While the risk of progression is greatest for CIN 3 lesions, not all of these lesions progress and regression is recognized to occur in a significant but variable number of cases [69]. Because of the slow rate of disease progression, targeting early detection at CIN 3 lesions is an effective strategy to avoid invasive cancer and at

${ }^{*}$ Corresponding author: Elizabeth R. Unger Ph.D., M.D., Centers for Disease Control and Prevention, 1600 Clifton Road, MS G41, Atlanta, GA 30333, USA. Tel: +1 404639 3533; Fax: +1 404639 3540; E-mail: eunger@cdc.gov. the same time avoid treatment of lesions that would be likely to resolve without intervention.

Pap smear screening is labor intensive and requires a dedicated highly-skilled workforce of cytotechnologists and pathologists as well as an extensive clinical infrastructure for follow-up, evaluation and treatment of women with cytologic abnormalities. Because of these requirements, human papillomavirus (HPV) is currently being investigated as an adjunct to cytology in cervical cancer screening. The recognition of the consistent and strong epidemiologic association of human papillomavirus (HPV) infection with development of cervical cancer, led to investigations of HPV testing as an approach to early detection. High-risk HPV types are accepted as oncogenic agents [1], and HPV is detected in more than $90 \%$ of cancers worldwide [61]. Currently HPV is viewed as a necessary but not sufficient factor for cervical cancer development. The recently completed prospective trial of HPV testing in the management of women with equivocal Pap smear results (ALTS trial) demonstrated improved sensitivity for detection of CIN 2/3 lesions compared with repeat cytology $[2,77]$. The improved sensitivity came at the expense of some reduction in specificity; however, the study justifies HPV testing as an alternative to repeat cervical cytology in women with equivocal cytology results.

HPV testing is also being considered as a screening test for cervical cancer $[23,30]$. While studies to date support the conclusion that a woman with a negative HPV test is very unlikely to have cervical cancer (i.e. 
HPV testing has very high negative predictive values), the clinical interpretation of positive result is not clear. HPV is the most prevalent sexually transmitted infection, and it is estimated that greater than $80 \%$ of sexually active people have been exposed. Prevalence is highest in young women near the onset of sexual activity and declines with age. Because high grade cervical dysplasia increases with age, limiting HPV screening to women over age 35, may improve the specificity of a positive result. Economic modeling clearly indicates that tests that increase the sensitivity of disease detection without improving the specificity will result in an increased cost for screening [63]. HPV testing is unlikely to achieve the specificity required for an effective adjunct to screening, so it is reasonable to look for other molecular markers of cervical neoplasia.

Biomarker discovery often begins with defining molecular events in the disease process, but the small size of cervical cancer precursors has made this difficult. Until very recently, only relatively large invasive lesions provided sufficient starting material for extraction and molecular analysis. Markers identified in invasive disease were then subsequently tested on the precursor lesions. Biomarkers were also suggested on the basis of known somatic genetic alterations in cervical cancer, from in vitro model systems of HPV transformation and from molecular changes noted in other cancers. Most studies characterizing the molecular features of CIN have relied on tissue-based techniques, such as immunohistochemistry and in situ hybridization, which allow localization of markers within the histologic context. Using techniques for gene and protein profiling applicable to very small lesions and limited numbers of cells, new candidate biomarkers specific for CIN 3 lesions can be directly sought.

The purpose of this review is to provide an overview of the large number of studies that have correlated a variety of markers with cervical cancer and preinvasive cervical neoplasia, and to highlight areas and approaches that appear most promising for early detection. While ideal early detection markers would be applicable to non-invasively collected samples, markers applied to histologic samples are included because those most promising could potentially be adapted to an alternative sampling approach. Many markers have been investigated since the 1980s, but specific citations emphasize publications within the past 5 years.

\section{Serum markers}

Serum has been the traditional sample for studies of tumor markers, however, relatively few studies have been done on cervical cancer, and even fewer have included preinvasive lesions (Table 1). Epidermal growth factor receptor (EGFR) is a tyrosine kinase signal transduction protein activated by the binding of EGF or transforming growth factor $\alpha$ to initiate cell proliferation and modulate other phenotypes of malignancy such as cell differentiation, motility and angiogenesis. EGFR is overexpressed in various malignancies, including 6-85\% of cervical carcinomas, so serum levels may correlate with disease. In comparison with normal controls, a small pilot study using an ELISA directed at the extracellular domain of EGFR noted a significant elevation in nearly all women with cancer (initial and recurrent) as well as with carcinoma in situ [68]. While these results are encouraging, sensitivity must be determined in a larger number of cases. In addition, because elevation of serum EGFR is associated with malignancies in addition to cervix, the finding is not specific and identification of the site of disease may be complicated.

Angiogenin (ANG) is a protein with ribonuclease activity involved in early angiogenesis. It binds to actin to activate tissue plasminogen activator that in turn generates plasmin which degrades laminin and fibronectin as a prelude to new vascular growth. Elevated serum ANG has been noted in various gynecologic malignancies, and was therefore investigated in women with cervical cancer and precancer. Elevated ANG was noted only in women with invasive disease so it is not a good candidate for early detection of cervical neoplasia [10]. The levels did not correlate with stage of disease, but longitudinal studies in an individual have not be performed to determine if the protein could serve as a biomarker to monitor disease response to therapy. Very similar findings were found for vascular endothelial growth factor (VEGF), another protein associated with angiogenesis [47].

Insulin-like growth factor-II (IGF-II) is a 67-amino acid peptide that mediates mitogenic and metabolic actions in a paracrine fashion. In circulation it is bound to IGF-binding protein-3 (IGF-BP3), IGF-binding protein 5 and acid-labile protein. IGF-II is detected in cervical cancer cell supernatants and alterations in IGF-II gene imprinting have been reported in several gynecologic malignancies. Recently serum levels of IGF-II and IGF-BP3 were determined in a small study [56]. Compared with controls and women with other gynecologic malignancies, those with abnormal Pap smears, CIN, and cervical cancer prior to therapy all had significant elevations of IGF-II. Women currently in remission after therapy for cervical cancer had serum IGF-II 
Table 1

Serum Markers

\begin{tabular}{|c|c|c|c|}
\hline Marker & Sample Number (Norm/Pre/Inv) & Conclusion & Ref \\
\hline EGFR & $76(38 / 12 / 26)$ & $\begin{array}{l}\text { Established cut-off from normal women. Elevated in } 92 \% \text { CIN } 3 \text { and } 92 \% \\
\text { cancer, levels significantly higher in invasive compared with noninvasive disease }\end{array}$ & {$[68]$} \\
\hline ANG & $139(30 / 47 / 62)$ & $\begin{array}{l}\text { Established cut-off from normal women. No elevation in CIN, } 81 \% \text { invasive } \\
\text { cancer }\end{array}$ & {$[10]$} \\
\hline VEGF & $147(35 / 28 / 84)$ & $\begin{array}{l}\text { Established cut-off from normal women. No elevation in CIN, } 75 \% \text { invasive } \\
\text { cancer }\end{array}$ & [47] \\
\hline $\begin{array}{l}\text { IGF-II } \\
\text { IGF-BP3 }\end{array}$ & $170(76 / 72 / 22)$ & $\begin{array}{l}\text { Includes } 23 \text { controls and } 53 \text { women with treated or no detected disease. Elevated } \\
\text { IFG-II in } 19 \% \text { of those with abnormal cytology and no disease, } 36 \% \text { of those } \\
\text { with cervical cancer in remission, } 100 \% \text { of those with cancer. Sensitivity of } \\
100 \% \text { and } 81 \% \text { for cancer and CIN respectively; specificity of } 87 \% \text { and } 82 \% \text {. } \\
\text { IGF-BP3 inversely related to IGF-II. Reduced serum levels have sensitivity of } \\
72 \% \text { and specificity of } 75 \% \text { for cervical cancer }\end{array}$ & [56] \\
\hline $\begin{array}{l}\text { Plasma HPV } \\
\text { DNA }\end{array}$ & $232(60 / 57 / 175)$ & Detected in $2 \%$ normal, $2 \% \mathrm{CIN}$ and $7 \%$ cancer & [25] \\
\hline
\end{tabular}

Norm = normal or no disease; Pre = preinvasive disease, all grades of CIN; INV = invasive cervical cancer.

$\mathrm{EGFR}=$ Epidermal growth factor receptor.

$\mathrm{ANG}=$ Angiogenin.

VEGF $=$ Vascular endothelial growth factor.

IGF-II = Insulin-like growth factor II.

IGF-BP3 = Insulin-like growth factor binding protein 3.

levels similar to controls. Using controls to establish a cut-off, IGF-II was $100 \%$ sensitive and $87 \%$ specific for invasive cervical cancer, whereas the corresponding values for CIN were $81 \%$ and $82 \%$ respectively. Serum IGF-BP3 was inversely related to IGF-II levels but was also decreased in women with other gynecologic malignancies and had a lower sensitivity and specificity for cervical cancer.

Circulating tumor DNA has been found in the serum and plasma of cancer patients. The mechanism whereby tumor DNA reaches the circulation is not clear, but may be related to tumor apoptosis or metastasis. For nasopharyngeal tumors that are associated with EBV and head and neck tumors associated with HPV, detection of viral DNA has been studied as a surrogate for circulating tumor DNA [14,50]. As shown in Table 1, detection of plasma HPV DNA did not have sensitivity or specificity for early detection of cervical cancer [25].

\section{Surrogates for HPV infection}

During normal epithelial differentiation, DNA replication is confined to cells in the basal layers. HPV interacts with numerous cellular targets to disrupt cellcycle control, allowing viral and cellular replication in differentiating cells [99]. In particular, the E6 and E7 oncoproteins of HPV interact with p53 and Rb and result in increased proliferation, decreased apoptosis and progressive accumulation of cellular DNA dam- age. With progressive dysplasia, the proliferative compartment expands to occupy the lower third of the epithelium in CIN 1, middle third in CIN 2, and fullthickness in CIN 3 and invasive cancer. As exfoliated cells come from the superficial layers of the epithelium, detecting proliferation in epithelial cells should not be expected in normal cervical cells. Cellular proteins involved in cell cycle regulation, proliferation and apoptosis are therefore reasonable candidates to explore as biomarkers of dysplasia because they are indicative of the oncogenic of HPV.

\subsection{Ki-67 (MIB-1), PCNA and Cyclin-E}

Ki-67 nuclear antigen is a non-histone protein detected in all active parts of the cell cycle. It is detected by monoclonal antibody MIB-1, and is sometimes referred to as MIB-1. Proliferating cell nuclear antigen (PCNA) is an S-phase associated nuclear protein involved in DNA repair and replication as an auxiliary factor for DNA polymerases- $\delta$ and $-\varepsilon$. Cyclin $\mathrm{E}$ is involved in cell cycle progression. The literature indicates that all of these markers do correlate with dysplasia and malignancy (for example $[6,31,41]$ ), and are used as an adjunct to histology. However, as proliferation is also associated with non-neoplastic conditions, such as inflammation, these markers have not gained widespread acceptance, and few applications in cytology samples have been reported. 


\section{2. $M C M$}

The minichromosome maintenance (MCM) proteins are a closely related family of proteins that function in DNA replication. MCM is a component of a cellular DNA helicase that forms a prereplicative complex permitting DNA replication. These proteins are good markers of proliferation as they are detectable during the proliferative phases of the cell cycle, but are lost when cells stop dividing and are not detected during DNA repair [31]. Antibodies to various MCMs localize to the nucleus and are effective in formalin-fixed material [31].

Several studies indicate the potential utility of MCM as an early detection marker for cervical neoplasia (Table 2). One study demonstrated that antibodies to MCM highlight abnormal cells in cytologic preparations, and allowed the detection of abnormal cells in smears that were originally evaluated as normal [92]. Because of MCM 7 overexpression in an HPV-transgenic mouse model of cervical cancer, MCM 7 was tested and found to correlate with the grade of dysplasia [11]. Additional study is required to determine the specificity and sensitivity of this marker in a larger number of cases, but the preliminary findings suggest that this family of markers is worthy of further investigation.

\subsection{Telomerase}

Telomerase is a specialized reverse transcriptase that maintains the length of telomeres at the end of eukaryotic chromosomes. Shortening of telomeres tends to occur during cell division and telomere reduction below a critical length is associated with cellular senescence, chromosomal instability and cell death. The holoenzme includes an RNA subunit (hTR) and a reverse transcriptase protein subunit (hTERT). The hTERT uses the internal RNA moiety as the template for DNA synthesis to extend telomeres. The activity of telomerase is normally restricted to the proliferative compartment of epithelium, and activation is associated with cellular immortalization and carcinogenesis.

The use of telomerase as a biomarker of cervical dysplasia and carcinoma has been recently reviewed [38, 41]. Several different assays have been used. The measurement of telomerase activity (TRAP; telomere repeat amplification protocol) is the current gold standard for telomerase expression, but requires fresh or snap frozen samples for enzyme preservation. Alternative measure of telomerase include RT-PCR for hRT and for hTERT mRNA. While most studies find increased ex- pression of telomerase in high-grade lesions and carcinomas, there are large variations (Table 2 ). In cervical cytology samples TRAP was detected in $0-11 \%$ normal, 12-63\% LSIL, 5-83\% HSIL and 31-100\% carcinomas [38]. Similar variations were observed with assays of hTR (ISH or RT-PCR) and hTERT mRNA (RTPCR). While tending to correlate with cervical disease progression, none of the assays of telomerase expression have sufficient sensitivity or specificity for early detection of cervical neoplasia.

\section{4. $p 16^{\mathrm{INK} 4 \mathrm{~A}}$}

p $16^{\mathrm{INK} 4 \mathrm{~A}}$ is a E2F responsive gene that functions as a cyclin-dependent kinase inhibitor. Through interaction with $\mathrm{pRB}$, the $\mathrm{E} 7$ protein of high risk HPVs release E2F. The resulting overexpression of $\mathrm{p} 16^{\mathrm{INK} 4 \mathrm{~A}}$ may therefore be more specific for HPV infections at highest risk of persisting. Antibodies to p16 ${ }^{\text {INK4A }}$ localize to both the nucleus and cytoplasm of positive cells. As shown in Table 2, numerous studies have examined the utility of $\mathrm{p} 16^{\mathrm{INK} 4 \mathrm{~A}}$ detection by IHC in biopsy and cytology material. There is agreement that $\mathrm{p} 16^{\mathrm{INK} 4 \mathrm{~A}}$ correlates with the degree of dysplasia. The positive reaction is useful for highlighting areas of abnormality and inter-observer agreement is good. Detection in varying numbers of inflammatory and benign endometrial cells suggests that detection of $\mathrm{p} 16^{\mathrm{INK} 4 \mathrm{~A}}$ without morphologic correlation will have limited specificity.

\section{5. $B r n-3 a$}

Brn-3a is a cellular transcription factor of the POU family. It has been shown to interact with the upstream regulatory region of HPV to activate transcription of HPV oncogenes E6 and E7. This marker has been studied by only one group of investigators (Table 2), and confirmation in additional studies will be required. However, the results are promising. One of the most interesting observations is the elevation of Brn-3a in normal epithelium surrounding CIN 3 lesions. This suggests Brn-3a correlates with a field effect of high grade cervical disease, so that a positive result would not be as easily missed due to sampling error. The Brn-3a assays were effective in cytology samples, an important consideration for a potential screening marker. 
Table 2

Surrogate HPV markers

\begin{tabular}{|c|c|c|c|c|}
\hline Marker & Method & $\begin{array}{l}\text { Sample } \\
\text { Number } \\
\text { (Norm/Pre/Inv) }\end{array}$ & Conclusion & Ref \\
\hline \multirow{3}{*}{$\begin{array}{l}\text { Minichromosome } \\
\text { Maintenance } \\
\text { Protein (MCM) } \\
\text { 7q21.3-q22.1 }\end{array}$} & $\begin{array}{l}\text { IHC (biopsy) } \\
\text { (cytology) } \\
\text { MCM } 5\end{array}$ & $\begin{array}{l}57(18 / 39 / 0) \\
58(30 / 25 / 3)\end{array}$ & $\begin{array}{l}\text { All smears from LSIL, HSIL and cancer positive; Positive MCM } \\
\text { detected } 4 \text { false negative samples because abnormal cells highlighted }\end{array}$ & [92] \\
\hline & $\begin{array}{l}\text { IHC } \\
\text { MCM 5, } \\
\text { MCM } 7\end{array}$ & $19(3 / 9 / 6)$ & $\begin{array}{l}\text { Number of positive nuclei on surface of lesions increases: CIN1 } \\
-50 \% \text {, CIN3 - >90\%. Number of positive cells increase: CIN0 } \\
14 / 17 \% \text {, CIN1 52/44\%, CIN3 98/97\%, Inv. Ca. } 95 / 94 \%\end{array}$ & {$[31]$} \\
\hline & $\begin{array}{l}\mathrm{IHC} \\
\mathrm{MCM} 7\end{array}$ & $34(13 / 13 / 8)$ & $\begin{array}{l}\text { Correlation of staining thickness of epithelium and severity of dys- } \\
\text { plasia: basal and parabasal in CIN0, } 1 / 3 \text { in CIN1 and }>90 \% \text { in CIN3 } \\
\text { and cancer }\end{array}$ & [11] \\
\hline \multirow[t]{6}{*}{ Telomerase } & $\begin{array}{l}\text { hTR and } \\
\text { hTERT } \\
\text { mRNA }\end{array}$ & $\begin{array}{l}98 \text { for ISH } \\
64 \text { for RT-PCR }\end{array}$ & $\begin{array}{l}\text { Upregulation of hTR (by ISH) and hTERT (by RT-PCR) in CIN and } \\
\text { cancers }\end{array}$ & [93] \\
\hline & $\begin{array}{l}\text { hTR and } \\
\text { hTERT } \\
\text { mRNA } \\
\text { (cytology) }\end{array}$ & $57(17 / 40 / 0)$ & $\begin{array}{l}\text { Not useful. hTR detected in } 82 \% \text { negative/CIN1 and } 92 \% \text { CIN } 2 / 3 \text {. } \\
\text { hTERT detected in } 6 \% \text { negative/CIN } 1 \text { and } 0 \% \text { CIN } 2 / 3\end{array}$ & [45] \\
\hline & $\begin{array}{l}\text { TRAP (bx) } \\
\text { (cytology) }\end{array}$ & $\begin{array}{l}62(17 / 16 / 29) \\
49(35 / 14 / 0)\end{array}$ & Activity in $0 \%$ normals, $69 \% \mathrm{CIN}$ and $97 \%$ cancer & [72] \\
\hline & $\begin{array}{l}\text { TRAP } \\
\text { (cytology) }\end{array}$ & $187(100 / 87 / 0)$ & $\begin{array}{l}\text { Activity in } 17 \% \text { normal/koilocytosis, } 41 \% \text { CIN } 1,40 \% \text { CIN 2, } 60 \% \\
\text { CIN 3; level significantly related to degree dysplasia }\end{array}$ & [35] \\
\hline & $\begin{array}{l}\text { TRAP } \\
\text { (cytology) }\end{array}$ & 93 & Activity in $0 \%$ normal, $69 \%$ CIN, $97 \%$ cancer & [79] \\
\hline & $\begin{array}{l}\text { TRAP } \\
\text { hTR and } \\
\text { hTERT } \\
\text { mRNA } \\
\text { (cytology) }\end{array}$ & $50(22 / 28 / 0)$ & $\begin{array}{l}\text { Not useful. TRAP in } 5 \% \text { normal/CIN } 1,0 \% \text { CIN } 2 / 3 \text {. hTR in } 100 \% \\
\text { normal/CIN } 1,88 \% \text { CIN } 2 / 3 \text {. hTERT in } 18 \% \text { normal CIN } 1,28 \% \\
\text { CIN } 2 / 3\end{array}$ & [73] \\
\hline \multirow[t]{8}{*}{$\mathrm{p} 16^{\mathrm{INK} 4 \mathrm{~A}}$} & $\mathrm{IHC}$ & $85(24 / 61 / 0)$ & Diffuse strong positive $0 \%$ normal, $38 \%$ LSIL, $70 \%$ HSIL & {$[40,41]$} \\
\hline & $\mathrm{IHC}$ & $\begin{array}{l}306 \\
(100 / 146 / 60)\end{array}$ & Positive in $0 \%$ normal, $87 \%$ CIN $1,100 \%$ CIN $2-3,97 \%$ cancer & [43] \\
\hline & $\mathrm{IHC}$ & 65 & Positive in most cancers and CIN with HR HPV & [75] \\
\hline & $\begin{array}{l}\text { IHC } \\
\text { (cytology) }\end{array}$ & $72(25 / 44 / 3)$ & $\begin{array}{l}\text { Positive in } 4 \% \text { normal, } 80 \% \text { CIN } 1,90 \% \text { CIN } 2 / 3,50 \% \text { AGUS and } \\
100 \% \text { cancer ( } 2 \text { adeno, } 1 \text { SCC) }\end{array}$ & [76] \\
\hline & IHC (tissue) & $154(22 / 122 / 10)$ & $\begin{array}{l}\text { Positive in } 0 \% \text { normal, } 99 \% \text { CIN, } 100 \% \text { cancer; mostly nuclear in } \\
\text { CIN 1, nuclear and cytoplasmic in glandular dysplasia, CIN } 2 / 3 \text { and } \\
\text { cancer }\end{array}$ & [62] \\
\hline & (cytology) & $33(12 / 21 / 0)$ & Highlights dysplastic cells & \\
\hline & $\mathrm{IHC}$ & $\begin{array}{l}569 \\
(247 / 269 / 53)\end{array}$ & $\begin{array}{l}\text { Positive in } 12 \% \text { negative, } 57 \% \text { CIN } 1,75 \% \text { CIN 2, } 91 \% \text { CIN 3, } 89 \% \\
\text { cancer. Positive in endometrium }\end{array}$ & [4] \\
\hline & $\mathrm{IHC}$ & $170(85 / 70 / 15)$ & Positive in $0 \%$ negative, $65 \% \mathrm{CIN} 1,100 \% \mathrm{CIN} 2 / 3,93 \%$ cancer & [3] \\
\hline \multirow[t]{3}{*}{ Brn-3a } & RT-PCR IHC & $30(16 / 14 / 0)$ & $\begin{array}{l}\text { CIN } 3 \text { and surrounding histologically normal epithelium show } 300 \\
\text { fold increase in Brn-3a RNA compare to normal }\end{array}$ & [64] \\
\hline & $\begin{array}{l}\text { RT-PCR } \\
\text { (cytology) }\end{array}$ & $147(0 / 147 / 0)$ & Positive in $68 \%$ with CIN2/3 & [81] \\
\hline & $\begin{array}{l}\text { RT-PCR } \\
\text { (cytology) }\end{array}$ & $202(74 / 162 / 2)$ & Expression increased with neoplastic progression & [82] \\
\hline
\end{tabular}

Norm $=$ normal or no disease; Pre $=$ preinvasive disease, all grades of CIN; INV = invasive cervical cancer.

Unless otherwise specified, assays are performed on tissues.

$\mathrm{IHC}=$ immunohistochemistry; RT-PCR $=$ Reverse transcription-Polymerase chain reaction. 


\section{Genetic markers}

Epithelial malignancies generally have very complex and confusing genetic changes, and cervical cancer is no exception. A summary of genetic changes known to occur in cervical cancer has been published recently [46]. Some of the most consistent changes at $3 p, 6 p$ and $11 q$ that have also been observed in high grade preinvasive lesions have been investigated as potential early detection markers using a variety of techniques such as fluorescent in situ hybridization (FISH), loss of heterozygosity ( $\mathrm{LOH}$, defined as absence or $50 \%$ reduction in intensity of one allele in tumor compared to normal) and methylation. Studies examining markers associated with genetic changes in cervical neoplasia are summarized in Table 3.

\subsection{3p loss and fragile histidine triad (FHIT)}

The $3 p$ locus is particularly interesting because it is also deleted in several other tumor types (renal, lung and nasopharyngeal carcinomas) and also contains a fragile site that is a frequent integration site for HPV16. $\mathrm{LOH}$ at $3 \mathrm{p}$ appears to be an early event in carcinogenesis whereas microsatellite instability occurs late. The role of microsatellite instability (MI, presence of new alleles, compared with normal) is controversial but it has been suggested that it renders cells susceptible to further genetic changes that could lead to malignancy. A potential tumor suppressor gene, fragile histidine triad (FHIT) has been mapped to 3p14.2. Loss of FHIT has been studied with immunohistochemistry (IHC) and abnormalities associated with transcription studied with RT-PCR. While abnormalities in FHIT are consistent findings in these studies, the sensitivity and specificity does not suggest that FHIT is a good candidate for early detection of cervical cancer

\subsection{DNA methylation}

Many cellular and viral genes are transcriptionally regulated by methylation in the $\mathrm{CpG}$ islands of their promoter regions. The potential role of hyper- or hypomethylation in carcinogenesis and as cancer-specific biomarkers is documented in recent reviews [39,70,88, 91]. There is direct evidence of methylation for at least 30 genes involved in breast carcinogenesis [91]. However, methylation status of only a very few genes has been studied in cervical carcinogenesis (Table 3). While cellular genes p16 and E-cadherin showed hypermethylation, LCR and E6 regions of HPV16 showed increasing hypomethylation with increasing cervical disease severity from high-grade lesions to cancer.

Since methylation assays are DNA based, disease specific methylation profiles can be more easily implemented as a screening or diagnostic marker compared to less stable RNA and protein based methods. However, methodological limitations exist with current methods including the widely used methylation-specific PCR (MSP) [70]. Newer methods such as restriction landmark genome scanning (RLGS [24]) DNA oligonucleotide arrays [96], MethylLight [26] and hairpinbisulfite PCR [44] may offer potential for genome-wide profiling, quantification, and determination of gain or loss of methylation.

\subsection{Loss of heterozygosity $(\mathrm{LOH})$}

$\mathrm{LOH}$ as a mechanism of carcinogenesis is assumed to involve deletion of tumor suppressor genes, however, in most cases the deletions are hemizygous leading one to speculate that in these cases the more effective allele is the one that has been deleted. A variety of chromosomal regions are lost during cervical carcinogenesis, but to date none have been consistent enough to have the sensitivity as an early marker of detection. In cytology samples, the abnormal cells compromise less than $10 \%$ of the total sample, so detecting $\mathrm{LOH}$ requires very sensitive assays. Approaches using a panel of LOH markers have been tried (Table 3), but to date, the sensitivity and specificity remain problematic.

\section{Other markers}

A wide variety of molecular markers associated with malignant transformation in other organs have been explored in the cervix as well. Recent summaries of surrogate endpoint biomarkers for cervical chemoprevention trials give an overview of the diversity of markers that correlate with cervical disease progression [28,29]. These studies have illustrated some of the many pathways altered during oncogenesis, but few have promise as specific and sensitive early detection markers. In the interest of brevity, only a few of the more recent reports and/or novel markers are summarized in Table 4. Most of these markers demonstrate significant and interesting changes during the pathogenesis of cervical cancer, but rely on a tissue context for interpretation. Some of these markers may be amenable to automated scoring, as demonstrated in the study of EGFR and transferrin receptors [42]. 
Table 3

DNA Changes Marker

\begin{tabular}{|c|c|c|c|c|}
\hline & Method & $\begin{array}{l}\text { Sample Number } \\
\text { (Norm/Pre/Inv) }\end{array}$ & Conclusion & Ref \\
\hline \multirow{9}{*}{$\begin{array}{l}\text { FHIT (fragile } \\
\text { histidine triad) } \\
\text { Tumor suppressor } \\
\text { 3p14.2 }\end{array}$} & RT-PCR & $69(21 / 13 / 35)$ & Abnormal transcripts in $0 \%$ normal, $0 \% \mathrm{CIN}, 40 \%$ cancers & [78] \\
\hline & IHC & $98(0 / 65 / 33)$ & Reduced in $61 \%$ squamous cancers, $33 \%$ HSIL & [9] \\
\hline & $\mathrm{IHC}$ & $212(22 / 95 / 95)$ & $\begin{array}{l}\text { Reduced in } 71 \% \text { cancers, } 52 \% \text { HSIL found with cancer, } 20 \% \text { HSIL without } \\
\text { cancer }\end{array}$ & {$[22]$} \\
\hline & $\mathrm{IHC}$ & $37(0 / 14 / 23)$ & Reduced in $65 \%$ cancers, $57 \%$ in situ cancers & [33] \\
\hline & $\begin{array}{l}\text { IHC } \\
\text { RT-PCR }\end{array}$ & $\begin{array}{l}58(6 / 22 / 30) \\
110(40 / 22 / 48)\end{array}$ & $\begin{array}{l}\text { Reduced in } 43 \% \text { cancers but not } \mathrm{CIN} \text { and normal } \\
\text { Full length transcripts in all normal and CIN but } 25 \% \text { normal and } 27 \% \\
\text { CIN also have aberrant transcripts; } 37 \% \text { cancers have aberrant or absent } \\
\text { transcripts }\end{array}$ & [97] \\
\hline & IHC (cytology) & $131(74 / 57 / 0)$ & Reduced in dysplasia & [87] \\
\hline & RT-PCR and IHC & $68(33 / 35 / 0)$ & $\begin{array}{l}\text { Full length transcripts in all, but } 20 \% \text { CIN and } 15 \% \text { normal also have } \\
\text { aberrant transcripts IHC matches RT-PCR }\end{array}$ & [49] \\
\hline & RT-PCR & $5(1 / 0 / 4)$ & Full length and truncated transcripts in all samples & [57] \\
\hline & $\mathrm{IHC}$ & $74(0 / 51 / 23)$ & Reduced in $50 \%$ CIN 3 and $78 \%$ cancer & [13] \\
\hline $\begin{array}{l}\text { hTERT Gene } \\
\text { amplification } \\
5 \mathrm{q} 31\end{array}$ & FISH, IHC & $91(0 / 3 / 88)$ & $\begin{array}{l}\text { hTERT gene amplification in cancers }(31 \%) \text { correlates with hTERT up- } \\
\text { regulation and HPV infection }\end{array}$ & [98] \\
\hline $\begin{array}{l}\text { TERC (RNA } \\
\text { component) gain } \\
3 q\end{array}$ & $\begin{array}{l}\text { FISH } \\
\text { (cytology) }\end{array}$ & $57(32 / 25)$ & $\begin{array}{l}92 \% \text { sensitivity and } 91 \% \text { specificity in detecting CIN } 2 / 3(23 / 25) \text { relative } \\
\text { to normal, atypical and LSIL ( } 3 / 32) \text { with threshold of } 2.5 \% \text { cells for TERC } \\
\text { genomic DNA amplification }\end{array}$ & {$[36]$} \\
\hline \multirow[t]{3}{*}{$\begin{array}{l}\text { DNA } \\
\text { Methylation } \\
\text { Markers }\end{array}$} & $\begin{array}{l}\text { MSP: } \\
\text { p16, RARß, } \\
F H I T, G S T P 1, \\
M G M T, \\
h M L H 1\end{array}$ & $73(30 / 24 / 19)$ & $\begin{array}{l}\text { Methylation of p16 and MGMT increased with disease ( } 3 \% \text { normal, } 24- \\
29 \% \text { CIN } 2 / 3 \text { and } 26-42 \% \text { cancers). One or more genes in panel methylated } \\
\text { in } 30 \% \text { normal, } 71 \% \text { CIN } 2 / 3 \text { and } 74 \% \text { cancer }\end{array}$ & [89] \\
\hline & $\begin{array}{l}\text { MSP: } \\
\text { E-cadherin }\end{array}$ & $30(10 / 0 / 20)$ & Hypermethylation in $0 \%$ normal, $40 \%$ cancer & [16] \\
\hline & $\begin{array}{l}\text { MSP: HPV } 16 \\
\text { LCR/E6 }\end{array}$ & $81(25 / 23 / 33)$ & Decreased methylation in $48 \%$ normal, $78 \%$ CIN, $94 \%$ cancer & [5] \\
\hline \multirow[t]{5}{*}{$\mathrm{LOH}$} & $\begin{array}{l}3 \mathrm{p} 14,3 \mathrm{p} 21 \\
3 \mathrm{p} 24,3 \mathrm{p} 25 \\
6 \mathrm{p} 21\end{array}$ & $\begin{array}{l}52 \text { tumor/control } \\
\text { pairs }\end{array}$ & $\begin{array}{l}\text { LOH seen at all } 6 \text { loci. Sensitivity } 96.7 \% \text {, specificity } 59.1 \% \text { with } \mathrm{LOH} \text { at } \\
\geqslant 1 \text { locus }\end{array}$ & [15] \\
\hline & $\begin{array}{l}3 \mathrm{p} \text { and } 6 \mathrm{p} \\
\text { Random primer } \\
\text { amplification }\end{array}$ & $57(0 / 33 / 24)$ & Frequent $\mathrm{LOH}$ at $3 \mathrm{p}$ and $6 \mathrm{p}$ & [71] \\
\hline & $\begin{array}{l}\text { Microsatellite } \\
\text { PCR for } 3 p, 6 p \text {, } \\
6 q\end{array}$ & $72(0 / 29 / 43)$ & $\begin{array}{l}\mathrm{LOH} \text { at } 3 p \text { is an early event, } \mathrm{MI} \text { is a late event assoc with progression of } \\
\mathrm{CIN} \text { to invasive cancer }\end{array}$ & [67] \\
\hline & $\begin{array}{l}\text { Microsatellite } \\
\text { PCR for } 3 p\end{array}$ & $19(0 / 19 / 0)$ & $\mathrm{LOH}$ at $3 p$ loci could be predictor of progression & [53] \\
\hline & $\begin{array}{l}\text { Multiplex PCR } \\
\text { for } 16 \\
\text { microsatellite } \\
\text { markers }\end{array}$ & $\begin{array}{l}37 \text { (19 recurrent } \\
\text { CIN and } 18 \text { non- } \\
\text { recurrent } \mathrm{CIN} \text { ) }\end{array}$ & $\mathrm{LOH}$ at $3 \mathrm{p} 14.2$ potential predictor for tumor recurrence & [48] \\
\hline
\end{tabular}

Norm = normal or no disease; Pre = preinvasive disease, all grades of CIN; INV = invasive cervical cancer.

Unless otherwise specified, assays are performed on tissues.

IHC = immunohistochemistry; RT-PCR = Reverse transcription-Polymerase chain reaction.

$\mathrm{FISH}=$ fluorescent in situ hybridization; MSP = methylation specific polymerase chain reaction.

$\mathrm{LOH}=$ loss of heterozygosity; $\mathrm{MI}=$ microsatellite instability. 
Table 4

Other markers Marker

\begin{tabular}{|c|c|c|c|c|}
\hline & Method & $\begin{array}{l}\text { Sample Number } \\
\text { (Norm/Pre/Inv) }\end{array}$ & Conclusion & Ref \\
\hline $\begin{array}{l}\text { Glucose } \\
\text { transporter } 1 \\
\text { (GLUT1) }\end{array}$ & IHC/ISH & $218(34 / 90 / 94)$ & $\begin{array}{l}\text { Expression restricted to basal layers in normal/CIN 1, increasing to full } \\
\text { thickness in CIN3 and cancer }\end{array}$ & [74] \\
\hline $\begin{array}{l}\text { Matrix } \\
\text { metalloproteinase } \\
\text { (MMP) }\end{array}$ & IHC & $54(10 / 29 / 15)$ & $\begin{array}{l}\text { Negative in normal and CIN } 1 \text {, MMP- } 2 \text { moderate to strong in } 38 \% \text { CIN } \\
2,80 \% \text { CIN 3,100\% cancers, MMP- } 1 \text { only in } 90 \% \text { cancer }\end{array}$ & {$[12]$} \\
\hline Laminin-5 & $\mathrm{IHC}$ & $90(0 / 55 / 35)$ & $\begin{array}{l}\text { Positive in } 4 \% \text { CIN } 1 / 2,34 \% \text { CIN } 3 \text { and } 100 \% \text { cancer. The one positive } \\
\text { CIN } 2 \text { was later shown to be cancer }\end{array}$ & [83] \\
\hline Metallothionein & IHC & $119(31 / 67 / 21)$ & $\begin{array}{l}\text { Confined to lower epithelium in all normal/CIN } 1 \text { and most CIN2, near } \\
\text { full-thickness in CIN } 3 \text { and cancer }\end{array}$ & [58] \\
\hline \multirow{2}{*}{$\begin{array}{l}\text { Epidermal } \\
\text { growth } \\
\text { factor receptor } \\
\text { (EGFR) }\end{array}$} & IHC & $42(12 / 20 / 10)$ & Positive in $90 \%$ cancer, $87 \%$ HSIL, $20 \%$ LSIL, $0 \%$ normal & [55] \\
\hline & IHC (cytology) & $63(15 / 48 / 0)$ & $\begin{array}{l}\text { Positive in } 100 \% \text { HSIL, } 85 \% \text { LSIL, } 78 \% \text { ASCUS, } 27 \% \text { normal. Auto- } \\
\text { mated assay }\end{array}$ & [42] \\
\hline $\begin{array}{l}\text { Transferrin } \\
\text { receptor }\end{array}$ & IHC (cytology) & $211(123 / 87 / 1)$ & $\begin{array}{l}\text { Positive in } 96 \% \text { HSIL /cancer, } 85 \% \text { LSIL, } 87 \% \text { atypical, } 19 \% \text { negative. } \\
\text { Automated assay }\end{array}$ & [42] \\
\hline $\begin{array}{l}\text { Erythropoietin } \\
\text { receptor (EpoR) }\end{array}$ & IHC & $170(85 / 70 / 15)$ & $\begin{array}{l}\text { Confined to lower epithelium in all normal/CIN } 1 \text { with progressive } \\
\text { increase to full-thickness in CIN } 3 \text { and cancer }\end{array}$ & [3] \\
\hline
\end{tabular}

Norm = normal or no disease; Pre = preinvasive disease, all grades of CIN; INV = invasive cervical cancer.

Unless otherwise specified, assays are performed on tissues.

$\mathrm{IHC}=$ immunohistochemistry; ISH $=$ in situ hybridization.

\section{Systematic search for markers}

New high-throughput technologies for gene, protein and metabolic analyses have the potential to allow an unbiased search for novel or unsuspected alterations specific to disease states. These methods were first applied to tissue culture and animal models of HPV transformation and only recently to tissue samples from women with invasive cervical cancer. To date none of the markers have been validated, however the approach is one of the most promising for the marker discovery process.

\subsection{Genomic}

Table 5 summarizes studies that have used gene expression profiling to identify potential biomarkers. In the largest study, genes commonly involved in cell proliferation or associated with the extracellular matrix were found to be up-regulated in squamous intraepithelial lesions and cancer [17]. Quantification of the most significant expression changes indicated a progressive increase from LSIL to HSIL to invasive cancer. The authors used in situ hybridization on tissue microarrays to examine the sensitivity and specificity of 17 top can- didates, and conclude than no one marker alone had the expected performance. Interestingly, MCM6 was identified as one of the most promising. As noted above, proteins in the MCM family were noted in other studies to be potential candidates for early detection. A novel cDNA fragment named C4.8 was discovered from gene profiling using differential display PCR of cDNA from tumorigenic versus non-tumorigenic HPV16 immortalized keratinoctyes [65]. This subsequently matched to a newly described gene NET-1, a new member of the tetraspanin superfamily [94]. This family of genes has been reported to play a role in many different functions including signal transduction, adhesion, migration, proliferation and differentiation. Using immunohistochemistry NET-I/C4.8 protein was found to be distinctly up-regulated in only a subset of high grade lesions and cancers [94]. NADH dehydrogenase 4 and a gene encoding ribosomal protein S12 were found to be significantly up-regulated not only in cancerous lesions but also in adjacent histopathological normal epithelium [19], indicating their potential as field effect markers of high grade lesions. Other genes that potentially identify high grade CIN and cervical carcinomas include up-regulation of IGF-BP3 [8] and downregulation of GATA-3 [86], a cellular transcription fac- 
Table 5

Studies using profiling

\begin{tabular}{|c|c|c|c|c|}
\hline Profile & Method & $\begin{array}{l}\text { Sample Number } \\
\text { (Norm/Pre/Inv) }\end{array}$ & Conclusion & Ref \\
\hline \multirow[t]{6}{*}{ Gene expression } & cDNA filter array & $10(5 / 0 / 5)$ & $\begin{array}{l}\text { Candidate markers identified, demonstration on few cell lines and } \\
\text { tumors }\end{array}$ & {$[80]$} \\
\hline & DD-PCR & $\begin{array}{l}\text { HPV model } \\
\text { system }\end{array}$ & $\begin{array}{l}\text { Candidate markers tested by ISH on tissue sections; Novel can- } \\
\text { didate gene NET-1/C4.8 found in subset HSIL, cancer }\end{array}$ & {$[65,94]$} \\
\hline & DD-PCR & $\begin{array}{l}6(6 / 0 / 6) ; \\
\text { Tumors with } \\
\text { normal margins }\end{array}$ & $\begin{array}{l}\text { Microarray and reverse northerns used to confirm candidate genes } \\
\text { in additional } 13 \text { tumor/normal tissue pairs. NADH dehydroge- } \\
\text { nase } 4 \text { and ribosome protein } 12 \text { identified as potential markers of } \\
\text { field effect }\end{array}$ & {$[18,19]$} \\
\hline & $\begin{array}{l}\text { cDNA } \\
\text { microarray }\end{array}$ & $\begin{array}{l}\text { HPV model } \\
\text { system }\end{array}$ & $\begin{array}{l}\text { Increased IGF BP-3 identified. ISH verification of expression in } \\
0 / 5 \text { normal, } 5 / 5 \text { HSIL }\end{array}$ & [8] \\
\hline & DD-PCR & HPV model system & $\begin{array}{l}\text { Reduced GATA-3 identified. ISH verification of expression in } \\
14 / 14 \text { normal, } 8 / 8 \text { CIN } 1 / 2,1 / 9 \text { CIN } 3,8 / 12 \text { cancers }\end{array}$ & [86] \\
\hline & $\begin{array}{l}\text { cDNA } \\
\text { microarray }\end{array}$ & $34(12 / 10 / 12)$ & $\begin{array}{l}\text { Candidate genes studied by ISH on tissue microarrays. None of } \\
62 \text { markers meet criteria for improved screening }\end{array}$ & [17] \\
\hline Fatty acid profile & $\begin{array}{l}\text { Gas-liquid } \\
\text { chromatography }\end{array}$ & $82(17 / 24 / 41)$ & $\begin{array}{l}\text { Linoleic acid (\% of total fatty acids) declined progressively from } \\
\text { normal }(17.9 \%) \text { to CIN }(14.0 \%) \text { to cancer }(9.5 \%) \text {. Significant } \\
\text { decrease in the level of saturated fatty acids and increase in mo- } \\
\text { nounsaturated fatty acids ( } \% \text { of total) from normal to CIN to } \\
\text { cancer }\end{array}$ & {$[51,52]$} \\
\hline Infrared spectra & $\begin{array}{l}\text { IR spectroscopy } \\
\text { of exfoliated } \\
\text { cervical cells }\end{array}$ & $156(136 / 8 / 12)$ & $\begin{array}{l}\text { IR spectral features of normal differed from dysplasia and cancer. } \\
\text { Glycogen reduced dramatically in cancer cells }\end{array}$ & {$[95]$} \\
\hline
\end{tabular}

Norm $=$ normal or no disease Pre $=$ preinvasive disease, all grades of CIN; INV $=$ invasive cervical cancer.

tor. However, as discussed above, decreased serum IGF-BP3 was associated with cervical neoplasia.

\subsection{Metabolomic}

Metabalomics is the process of characterizing a profile of the wide range of small molecules of metabolism such as fatty acids, lipids, nucleotides and peptides. Since disease often results in profound changes in cellular metabolism, this approach can be used to determine disease specific profiles and facilitate biomarker discovery [34]. Metabolic profiles can be generated from cellular extracts using a variety of analytic approaches such as gas chromatography/mass spectrophotometry (GC/MS), infrared spectroscopy or nuclear magnetic resonance (NMR). A recent study was able to generate distinct metabolic profiles for Arabidopsis genotypes using GC/MS, a concrete demonstration of the feasibility of the approach [27]. Although systematic studies have not yet been published on applications in cervical neoplasia, a few studies demonstrate the potential (Table 5). Using gas liquid chromatography on tissue extracts, Louw et al. [51] found a significant decrease in the content of linoleic acid in preinvasive lesions and cancers compared to normal cervix. Saturated fatty acids also declined but monounsaturated fatty acids increased with carcinogenesis [52].

Infrared (IR) spectroscopic studies of exfoliated cervical cells demonstrated significant spectral changes encompassing several bands discriminating normal, dysplastic and malignant cervical cells $[66,95]$. IR spectra indicated a dramatic and progressive decrease in the amount of glycogen from normal cells to dysplastic and cancer cells. This latter observation has been exploited clinically for many years to highlight dysplastic epithelium as non-staining areas after the application of iodine (the Lugol's test). Further systematic analysis of the metabolome as revealed in exfoliated cells, cervical mucous, urine, plasma or serum hold promise for biomarker discovery.

\subsection{Proteomic}

While it is estimated that the 30,000 transcripts from the human genome are a rich source for biomarker discovery, characterization of the human proteome will likely be more informative. This is because one transcript can represent hundreds of potential proteins because of alternate splicing strategies, posttranslational processing, protein structure and protein 
splicing. Characterization of the human proteome is linked to the completion of the human genome and depends on methods capable of resolving the many proteins that exist in complex biologic samples. Methods for protein characterization include multi-dimensional electrophoresis and mass spectroscopy. Integration of these two technologies allows for greater resolution and enumeration of the proteins in biological samples. To date, only very preliminary applications of proteomic techniques to cervical cancer have been published [7, 90]. Both studies used a mass spectroscopy technique called SELDI (surface enhanced laser desorption ionization) to profile the proteins in cell and tissue extracts. This emerging field has great potential to discover, identify, and validate proteins that could serve as early detection biomarkers. Studies that analyze noninvasively collected samples such as serum (plasma), urine or cervical mucous, are more likely to identify markers that could be easily adapted to a screening setting.

\section{Combining molecular markers with other technologies}

Given the biologic complexity of neoplasia, it is unlikely that any one biomarker will have the sensitivity and specificity required to improve early detection of cervical neoplasia. Combining multiple markers into a panel of tests is one solution to this problem. Another option would be to add molecular markers to existing screening technologies. Immunohistochemistry markers applied to the traditional cervical cytology platform have the potential to mark potentially abnormal cells to ensure they are not missed during screening, or to identify cells for careful cytogenetic analysis using FISH or similar technologies. MCM, discussed earlier, was shown to be effective in Pap smear materials, and may contribute to improved detection of abnormal cells [92]. Similarly, the observation that dysplastic cells have increased cervical acid phosphatase (CAP), has been combined with routine Pap smear preparations, to highlight abnormal cells using colorimetric enzyme histochemistry, the CAP-PAP ${ }^{\mathrm{TM}}$ test [54]. The effectiveness of these approaches to reduce false negative Pap smears, without introducing increased false positive results, awaits evaluation in much larger clinical trials.

The properties of cells change during neoplasia and this characteristic is exploited and detected using spectroscopic methods. Direct imaging of the cervix with spectroscopy involves illuminating the cervix with various wavelength emissions followed by capturing the reflected or fluorescent spectra with the same fiber optic probe. Both fluorescent and reflectance spectroscopy studies have been conducted and compared to the Pap smear, colposcopy, and cervicography for detecting SIL. As summarized in recent reviews, spectroscopic imaging was shown to have similar sensitivity and specificity of the Pap smear for screening [59] and similar sensitivity and specificity of colposcopy for diagnosing HGSIL [60]. It is possible that by combining fluorescent and reflectance spectroscopy techniques, better discrimination of SIL detection of the intact cervix can be accomplished.

Spectroscopy on saline collected exfoliated cervical cell pellets has shown very promising sensitivity and specificity for detection of abnormalities verified by biopsy at colposcopy, but studies are very limited and criteria for grades of dysplasia have not been established (see for example [32]). Only one study attempted Fourier-transform infrared spectroscopy on individual cells prepared for Pap smear screening [21]. They found that $95 \%$ of the exfoliated cells displayed 2 distinct spectral patterns. Interestingly, normal cells from women with dysplasia and cervical cancer differed from normal cells collected from women with normal morphology. Analysis of the spectra revealed a continuum of changes indicative of structural changes at the cellular level even though the cells were cytologically normal.

Additional imaging approaches are being developed that use optically active contrast agents to directly visualize molecular signatures of cervical cancer $[84,85]$. The goal of these approaches is to allow real-time diagnosis by imaging the intact cervix, so that women can receive definitive treatment at the time of the screening visit [20]. Significant improvements in imaging technology as well as refinement of the molecular targets for imaging will be required before this goal can be achieved.

\section{Conclusions}

In stark contrast to the large population-based trials used in the evaluation of cervicography, liquid-based cytology and HPV testing, conclusions about molecular markers have been reached on the basis of few samples. Of the 64 studies highlighted in Tables 1-5, the highest sample number was 569 . The vast majority $(59,98 \%)$ included 200 or less, and a little over half 
(34, 53\%) included less than 100 samples. The small numbers may be attributable to the fact that many of the assays have not been adapted to a high through-put screening format. In addition, pilot studies have not been encouraging enough to justify large scale validation studies. Combinations of markers identified by new techniques designed for systematic searches hold the most promise. It is clear that there is a large amount of research required before the molecular Pap smear becomes a reality. NCI's Early Detection Research Network, funded to initiate interdisciplinary collaborations advancing translational research in the area of early detection, is facilitating progress in this area.

\section{Acknowledgements}

Supported in part by NCI's Early Detection Research Network (EDRN), Interagency Agreement Y1CN-0101-01.

\section{References}

[1] Human papillomaviruses, IARC Monographs on the Evaluation of Carcinogenic Risks to Humans, International Agency for Research on Cancer World Health Organization 64 (1995), 1-409.

[2] Results of a randomized trial on the management of cytology interpretations of atypical squamous cells of undetermined significance, Am. J Obstet. Gynecol. 188 (2003), 1383-1392.

[3] G. Acs, P.J. Zhang, C.M. McGrath, P. Acs, J. McBroom, A. Mohyeldin, S. Liu, H. Lu and A. Verma, Hypoxia-inducible erythropoietin signaling in squamous dysplasia and squamous cell carcinoma of the uterine cervix and its potential role in cervical carcinogenesis and tumor progression, Am. J Pathol. 162 (2003), 1789-1806.

[4] S.N. Agoff, P. Lin, J. Morihara, C. Mao, N.B. Kiviat and L.A. Koutsky, p16(INK4a) expression correlates with degree of cervical neoplasia: a comparison with Ki-67 expression and detection of high-risk HPV types, Mod. Pathol. 16 (2003), $665-673$.

[5] V. Badal, L.S. Chuang, E.H. Tan, S. Badal, L.L. Villa, C.M. Wheeler, B.F. Li and H.U. Bernard, CpG methylation of human papillomavirus type 16 DNA in cervical cancer cell lines and in clinical specimens: genomic hypomethylation correlates with carcinogenic progression, J. Virol. 77 (2003), 62276234.

[6] P. Baldwin, R. Laskey and N. Coleman, Translational approaches to improving cervical screening, Nat. Rev. Cancer 3 (2003), 217-226.

[7] R.E. Banks, M.J. Dunn, M.A. Forbes, A. Stanley, D. Pappin, T. Naven, M. Gough, P. Harnden and P.J. Selby, The potential use of laser capture microdissection to selectively obtain distinct populations of cells for proteomic analysis-preliminary findings, Electrophoresis 20 (1999), 689-700.
[8] A.J. Berger, A. Baege, T. Guillemette, J. Deeds, R. Meyer, G. Disbrow, R. Schlegel and R. Schlegel, Insulin-like growth factor-binding protein 3 expression increases during immortalization of cervical keratinocytes by human papillomavirus type 16 E6 and E7 proteins, Am. J. Pathol. 161 (2002), 603610.

[9] M.J. Birrer, D. Hendricks, J. Farley, M.J. Sundborg, T. Bonome, M.J. Walts and J. Geradts, Abnormal Fhit expression in malignant and premalignant lesions of the cervix, Cancer Res 59 (1999), 5270-5274.

[10] B. Bodner-Adler, L. Hefler, K. Bodner, S. Leodolter, K. Frischmuth, C. Kainz and K. Mayerhofer, Serum levels of angiogenin (ANG) in invasive cervical cancer and in cervical intraepithelial neoplasia (CIN), Anticancer Res 21 (2001), 809-812.

[11] T. Brake, J.P. Connor, D.G. Petereit and P.F. Lambert, Comparative analysis of cervical cancer in women and in a human papillomavirus-transgenic mouse model: identification of minichromosome maintenance protein 7 as an informative biomarker for human cervical cancer, Cancer Res 63 (2003), 8173-8180.

[12] O. Brummer, G. Bohmer, B. Hollwitz, P. Flemming, K.U. Petry and H. Kuhnle, MMP-1 and MMP-2 in the cervix uteri in different steps of malignant transformation-an immunohistochemical study, Gynecol. Oncol. 84 (2002), 222-227.

[13] D. Butler, C. Collins, M. Mabruk, M.B. Leader and E.W. Kay, Loss of Fhit expression as a potential marker of malignant progression in preinvasive squamous cervical cancer, Gynecol. Oncol. 86 (2002), 144-149.

[14] R.B. Capone, S.I. Pai, W.M. Koch, M.L. Gillison, H.N. Danish, W.H. Westra, R. Daniel, K.V. Shah and D. Sidransky, Detection and quantitation of human papillomavirus (HPV) DNA in the sera of patients with HPV-associated head and neck squamous cell carcinoma, Clin. Cancer Res. 6 (2000), 4171-4175.

[15] C.L. Chang, S.Y. Wang, C.C. Wu, T.H. Su, K.L. Wang, H.S. Chen and Y.C. Yang, Microsatellite alterations in exfoliated cervical epithelia deoxyribonucleic acid as a marker for highgrade dysplasia, Am. J Obstet. Gynecol. 185 (2001), 108-115.

[16] C.L. Chen, S.S. Liu, S.M. Ip, L.C. Wong, T.Y. Ng and H.Y. Ngan, E-cadherin expression is silenced by DNA methylation in cervical cancer cell lines and tumours, Eur. J. Cancer 39 (2003), 517-523.

[17] Y. Chen, C. Miller, R. Mosher, X. Zhao, J. Deeds, M. Morrissey, B. Bryant, D. Yang, R. Meyer, F. Cronin, B.S. Gostout, K. Smith-McCune and R. Schlegel, Identification of cervical cancer markers by cDNA and tissue microarrays, Cancer Res 63 (2003), 1927-1935.

[18] Q. Cheng, W.M. Lau, S.H. Chew, T.H. Ho, S.K. Tay and K.M. Hui, Identification of molecular markers for the early detection of human squamous cell carcinoma of the uterine cervix, $\mathrm{Br}$. J. Cancer 86 (2002), 274-281.

[19] Q. Cheng, W.M. Lau, S.K. Tay, S.H. Chew, T.H. Ho and K.M. Hui, Identification and characterization of genes involved in the carcinogenesis of human squamous cell cervical carcinoma, Int. J. Cancer 98 (2002), 419-426.

[20] L.P. Clarke, H. Baker and G. Kelloff, Foreword: potential of optical imaging for early cancer detection, screening, diagnosis and image guided treatment, Technol. Cancer Res Treat. 2 (2003), 487-490.

[21] M.A. Cohenford and B. Rigas, Cytologically normal cells from neoplastic cervical samples display extensive structural abnormalities on IR spectroscopy: implications for tumor biology, Proc. Natl. Acad. Sci. USA 95 (1998), 15327-15332. 
[22] D.C. Connolly, D.L. Greenspan, R. Wu, X. Ren, R.L. Dunn, K.V. Shah, R.W. Jones, F.X. Bosch, N. Munoz and K.R. Cho, Loss of fhit expression in invasive cervical carcinomas and intraepithelial lesions associated with invasive disease, Clin Cancer Res 6 (2000), 3505-3510.

[23] J. Cuzick, A. Szarewski, H. Cubie, G. Hulman, H. Kitchener, D. Luesley, E. McGoogan, U. Menon, G. Terry, R. Edwards, C. Brooks, M. Desai, C. Gie, L. Ho, I. Jacobs, C. Pickles and P. Sasieni, Management of women who test positive for highrisk types of human papillomavirus: the HART study, Lancet 362 (2003), 1871-1876.

[24] Z. Dai, R.R. Lakshmanan, W.G. Zhu, D.J. Smiraglia, L.J. Rush, M.C. Fruhwald, R.M. Brena, B. Li, F.A. Wright, P. Ross, G.A. Otterson and C. Plass, Global methylation profiling of lung cancer identifies novel methylated genes, Neoplasia 3 (2001), 314-323.

[25] S.M. Dong, S.I. Pai, S.H. Rha, A. Hildesheim, R.J. Kurman, P.E. Schwartz, R. Mortel, L. McGowan, M.D. Greenberg, W.A. Barnes and D. Sidransky, Detection and quantitation of human papillomavirus DNA in the plasma of patients with cervical carcinoma, Cancer Epidemiol. Biomarkers Prev. 11 (2002), 3-6.

[26] C.A. Eads, K.D. Danenberg, K. Kawakami, L.B. Saltz, C. Blake, D. Shibata, P.V. Danenberg and P.W. Laird, MethyLight: a high-throughput assay to measure DNA methylation, Nucleic Acids Res 28 (2000), E32.

[27] O. Fiehn, J. Kopka, P. Dormann, T. Altmann, R.N. Trethewey and L. Willmitzer, Metabolite profiling for plant functional genomics, Nat. Biotechnol. 18 (2000), 1157-1161.

[28] M. Follen, F.L. Meyskens, Jr., R.D. Alvarez, J.L. Walker, M.C. Bell, K.A. Storthz, J. Sastry, K. Roy, R. Richards-Kortum and T.L. Cornelison, Cervical cancer chemoprevention, vaccines and surrogate endpoint biomarkers, Cancer 98 (2003), 20442051.

[29] M. Follen and D. Schottenfeld, Surrogate endpoint biomarkers and their modulation in cervical chemoprevention trials, Cancer 91 (2001), 1758-1776.

[30] E.L. Franco, Are we ready for a paradigm change in cervical cancer screening? Lancet 362 (2003), 1866-1867.

[31] A. Freeman, L.S. Morris, A.D. Mills, K. Stoeber, R.A. Laskey, G.H. Williams and N. Coleman, Minichromosome maintenance proteins as biological markers of dysplasia and malignancy, Clin Cancer Res 5 (1999), 2121-2132.

[32] M. Fung Kee Fung, M. Senterman, P. Eid, W. Faught, N.Z. Mikhael and P.T. Wong, Comparison of Fourier-transform infrared spectroscopic screening of exfoliated cervical cells with standard Papanicolaou screening, Gynecol. Oncol. 66 (1997), $10-15$.

[33] E. Giarnieri, R. Mancini, T. Pisani, M. Alderisio and A. Vecchione, Msh2, Mlh1, Fhit, p53, Bcl-2 and Bax expression in invasive and in situ squamous cell carcinoma of the uterine cervix, Clin Cancer Res 6 (2000), 3600-3606.

[34] N. Glassbrook, C. Beecher and J. Ryals, Metabolic profiling on the right path, Nat. Biotechnol. 18 (2000), 1142-1143.

[35] M. Herbsleb, U.B. Knudsen, T.F. Orntoft, P. Bichel, B. Norrild, A. Knudsen and O. Mogensen, Telomerase activity, MIB-1, PCNA, HPV 16 and p53 as diagnostic markers for cervical intraepithelial neoplasia, Apmis 109 (2001), 607-617.

[36] K. Heselmeyer-Haddad, V. Janz, P.E. Castle, N. Chaudhri, N. White, K. Wilber, L.E. Morrison, G. Auer, F.H. Burroughs, M.E. Sherman and T. Ried, Detection of genomic amplification of the human telomerase gene (TERC) in cytologic specimens as a genetic test for the diagnosis of cervical dysplasia, Am. J Pathol. 163 (2003), 1405-1416.
[37] P. Holowaty, A.B. Miller, T. Rohan and T. To, Natural history of dysplasia of the uterine cervix, $J$ Natl. Cancer Inst. 91 (1999), 252-258.

[38] E.A. Jarboe, K.L. Liaw, L.C. Thompson, D.E. Heinz, P.L. Baker, J.A. McGregor, T. Dunn, J.E. Woods and K.R. Shroyer, Analysis of telomerase as a diagnostic biomarker of cervical dysplasia and carcinoma, Oncogene 21 (2002), 664-673.

[39] A.M. Jubb, P. Quirke and A.J. Oates, DNA methylation, a biomarker for colorectal cancer: implications for screening and pathological utility, Ann. N. Y. Acad. Sci. 983 (2003), 251-267.

[40] J.T. Keating, A. Cviko, S. Riethdorf, L. Riethdorf, B.J. Quade, D. Sun, S. Duensing, E.E. Sheets, K. Munger and C.P. Crum, $\mathrm{Ki}-67$, cyclin $\mathrm{E}$ and $\mathrm{p} 16 \mathrm{INK} 4$ are complimentary surrogate biomarkers for human papilloma virus-related cervical neoplasia, Am. J Surg. Pathol. 25 (2001), 884-891.

[41] J.T. Keating, T. Ince and C.P. Crum, Surrogate biomarkers of HPV infection in cervical neoplasia screening and diagnosis, Adv. Anat. Pathol. 8 (2001), 83-92.

[42] S.K. Keesee, R. Domanik and B. Patterson, Fully automated proteomic detection of cervical dysplasia, Anal. Quant. Cytol. Histol. 24 (2002), 137-146.

[43] R. Klaes, T. Friedrich, D. Spitkovsky, R. Ridder, W. Rudy, U. Petry, G. Dallenbach-Hellweg, D. Schmidt and D.M. von Knebel, Overexpression of p16(INK4A) as a specific marker for dysplastic and neoplastic epithelial cells of the cervix uteri, Int. J Cancer 92 (2001), 276-284.

[44] C.D. Laird, N.D. Pleasant, A.D. Clark, J.L. Sneeden, K.M. Hassan, N.C. Manley, J.C. Vary, Jr., T. Morgan, R.S. Hansen and R. Stoger, From The Cover: Hairpin-bisulfite PCR: Assessing epigenetic methylation patterns on complementary strands of individual DNA molecules, Proc. Natl. Acad. Sci. USA 101 (2004), 204-209.

[45] S. Lanham, A. Herbert and P. Watt, HPV detection and measurement of HPV-16, telomerase and survivin transcripts in colposcopy clinic patients, J Clin. Pathol. 54 (2001), 304-308.

[46] P.A. Lazo, The molecular genetics of cervical carcinoma, $B r$. J. Cancer 80 (1999), 2008-2018.

[47] A. Lebrecht, E. Ludwig, A. Huber, M. Klein, C. Schneeberger, C. Tempfer, H. Koelbl and L. Hefler, Serum vascular endothelial growth factor and serum leptin in patients with cervical cancer, Gynecol. Oncol. 85 (2002), 32-35.

[48] W.M. Lin, E.A. Michalopulos, N. Dhurander, P.C. Cheng, W. Robinson, R. Ashfaq, R.L. Coleman and C.Y. Muller, Allelic loss and microsatellite alterations of chromosome 3p14.2 are more frequent in recurrent cervical dysplasias, Clin Cancer Res 6 (2000), 1410-1414.

[49] F.S. Liu, Y.T. Hsieh, J.T. Chen, E.S. Ho, M.J. Hung and A.J. Lin, FHIT (fragile histidine triad) gene analysis in cervical intraepithelial neoplasia, Gynecol. Oncol. 82 (2001), 283-290.

[50] Y.M. Lo, L.Y. Chan, A.T. Chan, S.F. Leung, K.W.Lo, J. Zhang, J.C. Lee, N.M. Hjelm, P.J. Johnson and D.P. Huang, Quantitative and temporal correlation between circulating cell-free Epstein-Barr virus DNA and tumor recurrence in nasopharyngeal carcinoma, Cancer Res 59 (1999), 5452-5455.

[51] L. Louw, A.M. Engelbrecht and F. Cloete, Comparison of the fatty acid compositions in intraepithelial and infiltrating lesions of the cervix: part I, total fatty acid profiles, Prostaglandins Leukot. Essent. Fatty Acids 59 (1998), 247251.

[52] L. Louw, A.M. Engelbrecht and F. Cloete, Comparison of the fatty acid compositions in intraepithelial and infiltrating lesions of the cervix: part III, saturated and unsaturated fatty 
acid profiles, Prostaglandins Leukot. Essent. Fatty Acids 59 (1998), 259-264.

[53] F. Luft, J. Gebert, A. Schneider, P. Melsheimer and D. von Knebel, Frequent allelic imbalance of tumor suppressor gene loci in cervical dysplasia, Int. J. Gynecol. Pathol. 18 (1999), 374-380.

[54] O. Markovic and N. Markovic, Can acid phosphatase reduce pap test false-negative readings? J Natl. Cancer Inst. 89 (1997), 1459.

[55] S.P. Mathur, R.S. Mathur, P.F. Rust and R.C. Young, Human papilloma virus (HPV)-E6/E7 and epidermal growth factor receptor (EGF-R) protein levels in cervical cancer and cervical intraepithelial neoplasia (CIN), Am. J Reprod. Immunol 46 (2001), 280-287.

[56] S.P. Mathur, R.S. Mathur, P.B. Underwood, M.F. Kohler and W.T. Creasman, Circulating levels of insulin-like growth factor-II and IGF-binding protein 3 in cervical cancer, $G y$ necol. Oncol. 91 (2003), 486-493.

[57] C.P. Matthews, K. Shera, N. Kiviat and J.K. McDougall, Expression of truncated FHIT transcripts in cervical cancers and in normal human cells, Oncogene 20 (2001), 4665-4675.

[58] W.G. McCluggage, P. Maxwell and H. Bharucha, Immunohistochemical detection of metallothionein and MIB1 in uterine cervical squamous lesions, Int J Gynecol. Pathol. 17 (1998), 29-35.

[59] M.F. Mitchell, S.B. Cantor, C. Brookner, U. Utzinger, D. Schottenfeld and R. Richards-Kortum, Screening for squamous intraepithelial lesions with fluorescence spectroscopy, Obstet. Gynecol. 94 (1999), 889-896.

[60] M.F. Mitchell, S.B. Cantor, N. Ramanujam, G. Tortolero-Luna and R. Richards-Kortum, Fluorescence spectroscopy for diagnosis of squamous intraepithelial lesions of the cervix, Obstet. Gynecol. 93 (1999), 462-470.

[61] N. Munoz, F.X. Bosch, S. de Sanjose, R. Herrero, X. Castellsague, K.V. Shah, P.J. Snijders and C.J. Meijer, Epidemiologic classification of human papillomavirus types associated with cervical cancer, N. Engl. J. Med. 348 (2003), 518-527.

[62] N. Murphy, M. Ring, A.G. Killalea, V. Uhlmann, M. O'Donovan, F. Mulcahy, M. Turner, E. McGuinness, M. Griffin, C. Martin, O. Sheils and J.J. O'Leary, p16 ${ }^{\mathrm{INK} 4 \mathrm{~A}}$ as a marker for cervical dyskaryosis: CIN and cGIN in cervical biopsies and ThinPrep smears, J Clin Pathol 56 (2003), 56-63.

[63] E.R. Myers, D.C. McCrory, S. Subramanian, N. McCall, K. Nanda, S. Datta and D.B. Matchar, Setting the target for a better cervical screening test: characteristics of a cost-effective test for cervical neoplasia screening, Obstet. Gynecol. 96 (2000), 645-652.

[64] D. Ndisdang, P.J. Morris, C. Chapman, L. Ho, A. Singer, and D.S. Latchman, The HPV-activating cellular transcription factor Brn-3a is overexpressed in CIN3 cervical lesions, J Clin Invest 101 (1998), 1687-1692.

[65] M. Nees, E. van Wijngaarden, E. Bakos, A. Schneider and M. Durst, Identification of novel molecular markers which correlate with HPV- induced tumor progression, Oncogene 16 (1998), 2447-2458.

[66] S. Neviliappan, K.L. Fang, W.T. Tiang Lee, S. Arulkumaran, and P.T. Wong, Infrared spectral features of exfoliated cervical cells, cervical adenocarcinoma tissue and an adenocarcinoma cell line (SiSo), Gynecol. Oncol. 85 (2002), 170-174.

[67] M. Nishimura, H. Furumoto, T. Kato, M. Kamada and T. Aono, Microsatellite instability is a late event in the carcinogenesis of uterine cervical cancer, Gynecol. Oncol. 79 (2000), 201-206.

[68] M.J. Oh, J.H. Choi, I.H. Kim, Y.H. Lee, J.Y. Huh, Y.K. Park, K.W. Lee, S.Y. Chough, K.S. Joo, B.S. Ku and H.S. Saw,
Detection of epidermal growth factor receptor in the serum of patients with cervical carcinoma, Clin Cancer Res 6 (2000), 4760-4763.

[69] A.G. Ostor, Natural history of cervical intraepithelial neoplasia: a critical review, Int J Gynecol. Pathol. 12 (1993), 186192.

[70] A. Patel, J.D. Groopman and A. Umar, DNA methylation as a cancer-specific biomarker: from molecules to populations, Ann. N. Y. Acad. Sci. 983 (2003), 286-297.

[71] J.S. Rader, D.S. Gerhard, M.J. O’Sullivan, Y. Li, L. Li, H. Liapis and P.C. Huettner, Cervical intraepithelial neoplasia III shows frequent allelic loss in 3p and 6p, Genes Chromosomes. Cancer 22 (1998), 57-65.

[72] V.G. Reddy, N. Khanna, S.K. Jain, B.C. Das and N. Singh, Telomerase-A molecular marker for cervical cancer screening, Int. J. Gynecol. Cancer 11 (2001), 100-106.

[73] N. Reesink-Peters, M.N. Helder, G.B. Wisman, A.J. Knol, S. Koopmans, H.M. Boezen, E. Schuuring, H. Hollema, E.G. de Vries, S. de Jong and A.G. van der Zee, Detection of telomerase, its components, and human papillomavirus in cervical scrapings as a tool for triage in women with cervical dysplasia, J. Clin. Pathol. 56 (2003), 31-35.

[74] C. Rudlowski, A.J. Becker, W. Schroder, W. Rath, R. Buttner and M. Moser, GLUT1 messenger RNA and protein induction relates to the malignant transformation of cervical cancer, $A m$. J Clin Pathol. 120 (2003), 691-698.

[75] T. Sano, N. Masuda, T. Oyama and T. Nakajima, Overexpression of p16 and p14ARF is associated with human papillomavirus infection in cervical squamous cell carcinoma and dysplasia, Pathol. Int. 52 (2002), 375-383.

[76] A. Saqi, T.L. Pasha, C.M. McGrath, G.H. Yu, P. Zhang and P. Gupta, Overexpression of $\mathrm{p} 16^{\mathrm{INK} 4 \mathrm{~A}}$ in liquid-based specimens (SurePath) as marker of cervical dysplasia and neoplasia, Diagn. Cytopathol. 27 (2002), 365-370.

[77] M. Schiffman and D. Solomon, Findings to date from the ASCUS-LSIL Triage Study (ALTS), Arch Pathol. Lab Med 127 (2003), 946-949.

[78] T. Segawa, T. Sasagawa, H. Yamazaki, J. Sakaike, H. Ishikawa and $\mathrm{M}$. Inoue, Fragile histidine triad transcription abnormalities and human papillomavirus E6-E7 mRNA expression in the development of cervical carcinoma, Cancer 85 (1999), 2001-2010.

[79] S. Sen, V.G. Reddy, R. Guleria, S.K. Jain, K. Kapila and N. Singh, Telomerase-a potential molecular marker of lung and cervical cancer, Clin Chem. Lab Med 40 (2002), 994-1001.

[80] C. Shim, W. Zhang, C.H. Rhee and J.H. Lee, Profiling of differentially expressed genes in human primary cervical cancer by complementary DNA expression array, Clin. Cancer Res. 4 (1998), 3045-3050.

[81] M. Sindos, D. Ndisang, N. Pisal, C. Chow, A. Deery, A. Singer and D. Latchman, Detection of cervical neoplasia using measurement of Brn-3a in cervical smears with persistent minor abnormality, Int. J Gynecol. Cancer 13 (2003), 515-517.

[82] M. Sindos, D. Ndisang, N. Pisal, C. Chow, A. Singer and D.S. Latchman, Measurement of Brn-3a levels in Pap smears provides a novel diagnostic marker for the detection of cervical neoplasia, Gynecol. Oncol. 90 (2003), 366-371.

[83] B. Skyldberg, S. Salo, E. Eriksson, U. Aspenblad, B. Moberger, K. Tryggvason and G. Auer, Laminin-5 as a marker of invasiveness in cervical lesions, J Natl. Cancer Inst. 91 (1999), 1882-1887.

[84] K. Sokolov, J. Aaron, B. Hsu, D. Nida, A. Gillenwater, M. Follen, C. Macaulay, K. Adler-Storthz, B. Korgel, M. Descour, R. Pasqualini, W. Arap, W. Lam and R. Richards-Kortum, Op- 
tical systems for in vivo molecular imaging of cancer, Technol. Cancer Res Treat. 2 (2003), 491-504.

[85] K. Sokolov, M. Follen and R. Richards-Kortum, Optical spectroscopy for detection of neoplasia, Curr. Opin. Chem. Biol 6 (2002), 651-658

[86] R.D. Steenbergen, V.E. OudeEngberink, D. Kramer, H.F. Schrijnemakers, R.H. Verheijen, C.J. Meijer and P.J. Snijders, Down-regulation of GATA-3 expression during human papillomavirus-mediated immortalization and cervical carcinogenesis, Am. J. Pathol. 160 (2002), 1945-1951.

[87] A. Vecchione, N. Zanesi, G. Trombetta, D. French, P. Visca, T. Pisani, C. Botti, A. Vecchione, C.M. Croce and R. Mancini, Cervical dysplasia, ploidy, and human papillomavirus status correlate with loss of Fhit expression, Clin Cancer Res 7 (2001), 1306-1312.

[88] M. Verma, Viral genes and methylation, Ann. N. Y. Acad. Sci. 983 (2003), 170-180.

[89] A.K. Virmani, C. Muller, A. Rathi, S. Zoechbauer-Mueller, M. Mathis and A.F. Gazdar, Aberrant methylation during cervical carcinogenesis, Clin. Cancer Res 7 (2001), 584-589.

[90] F. Von Eggeling, K. Junker, W. Fiedle, V. Wollscheid, M. Durst, U. Claussen and G. Ernst, Mass spectrometry meets chip technology: a new proteomic tool in cancer research? Electrophoresis 22 (2001), 2898-2902.

[91] M. Widschwendter and P.A. Jones, DNA methylation and breast carcinogenesis, Oncogene 21 (2002), 5462-5482.

[92] G.H. Williams, P. Romanowski, L. Morris, M. Madine, A.D. Mills, K. Stoeber, J. Marr, R.A. Laskey and N. Coleman, Improved cervical smear assessment using antibodies against proteins that regulate DNA replication, Proc. Natl. Acad. Sci. USA 95 (1998), 14932-14937.
[93] G.B. Wisman, S. de Jong, G.J. Meersma, M.N. Helder, H. Hollema, E.G. de Vries, W.N. Keith and A.G. van der Zee, Telomerase in (pre) neoplastic cervical disease, Hum. Pathol. 31 (2000), 1304-1312.

[94] V. Wollscheid, R. Kuhne-Heid, I. Stein, L. Jansen, S. Kollner, A. Schneider and M. Durst, Identification of a new proliferation-associated protein NET-1/C4.8 characteristic for a subset of high-grade cervical intraepithelial neoplasia and cervical carcinomas, Int J Cancer 99 (2002), 771-775.

[95] P.T. Wong, R.K. Wong, T.A. Caputo, T.A. Godwin and B. Rigas, Infrared spectroscopy of exfoliated human cervical cells: evidence of extensive structural changes during carcinogenesis, Proc. Natl. Acad. Sci. USA 88 (1991), 10988-10992.

[96] P.S. Yan, C.M. Chen, H. Shi, F. Rahmatpanah, S.H. Wei, C.W. Caldwell and T.H. Huang, Dissecting complex epigenetic alterations in breast cancer using $\mathrm{CpG}$ island microarrays, Cancer Res 61 (2001), 8375-8380.

[97] K. Yoshino, T. Enomoto, T. Nakamura, H. Sun, K. Ozaki, R. Nakashima, H. Wada, J. Saitoh, Y. Watanabe, K. Noda and Y. Murata, FHIT alterations in cancerous and non-cancerous cervical epithelium, Int J Cancer 85 (2000), 6-13.

[98] A. Zhang, C. Zheng, M. Hou, C. Lindvall, K.L. Wallin, T. Angstrom, X. Yang, A.C. Hellstrom, E. Blennow, M. Bjorkholm, A. Zetterberg, A. Gruber and D. Xu, Amplification of the telomerase reverse transcriptase (hTERT), gene in cervical carcinomas, Genes Chromosomes. Cancer 34 (2002), 269-275.

[99] H. zur Hausen, Papillomaviruses and cancer: from basic studies to clinical application, Nat. Rev. Cancer 2 (2002), 342350 . 


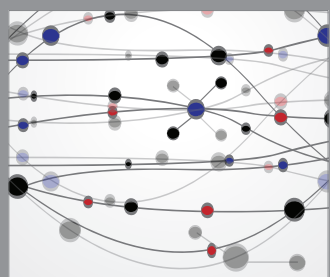

The Scientific World Journal
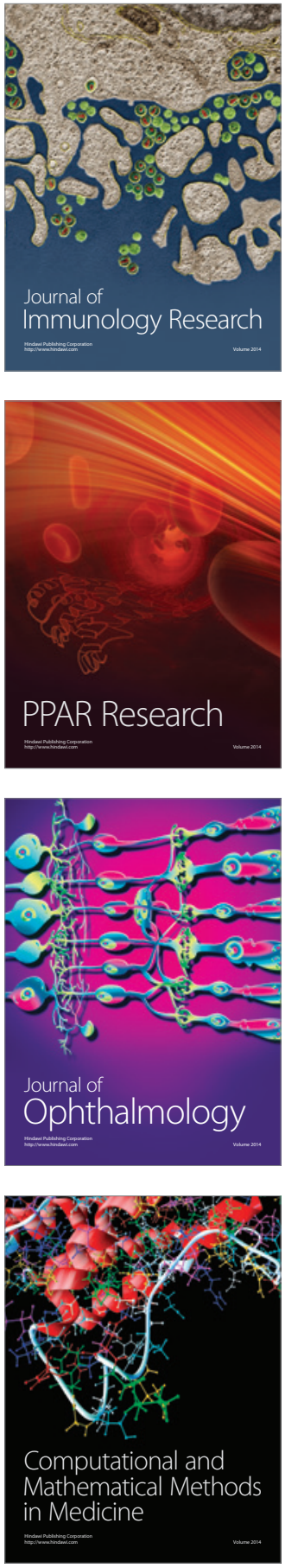

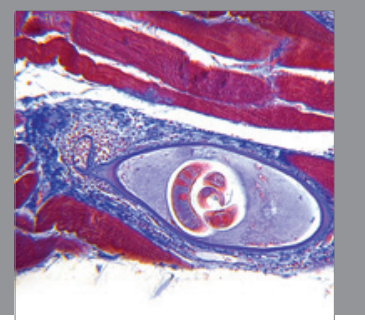

Gastroenterology

Research and Practice
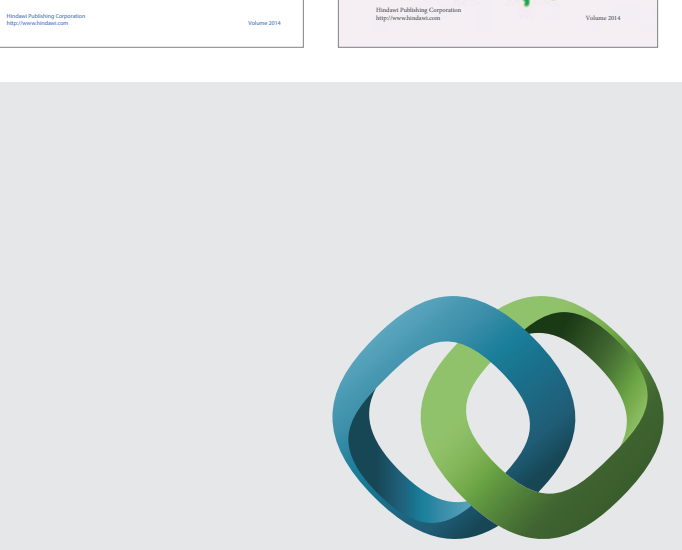

\section{Hindawi}

Submit your manuscripts at

http://www.hindawi.com
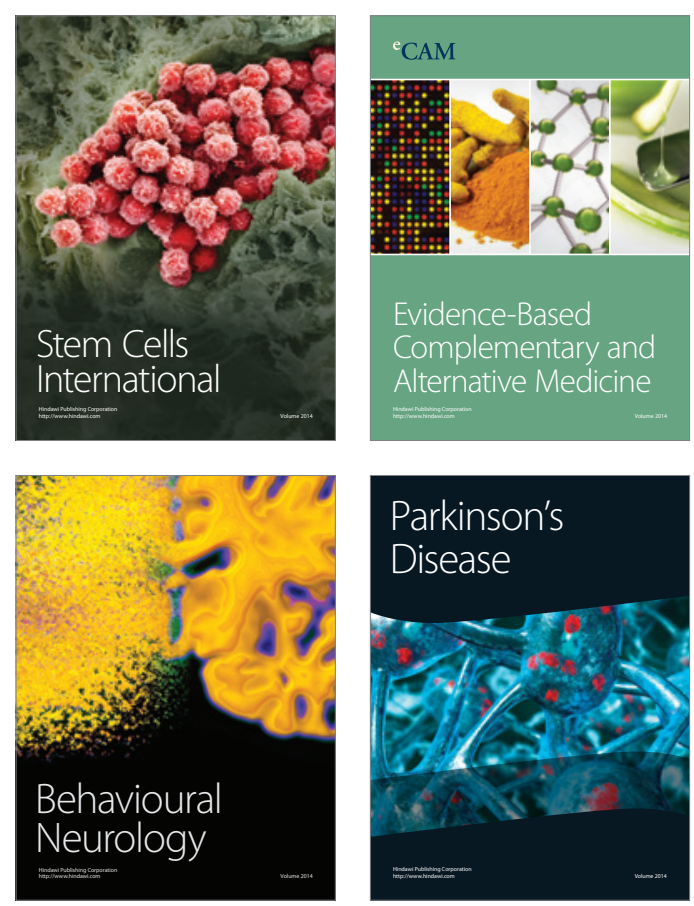

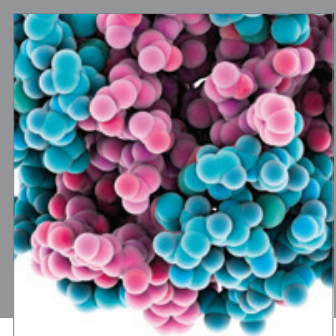

Journal of
Diabetes Research

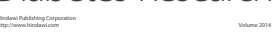

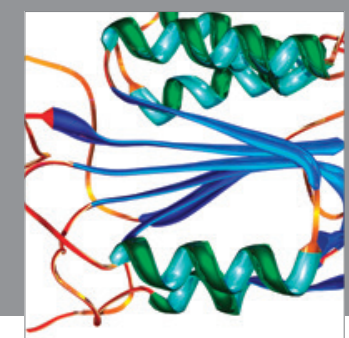

Disease Markers
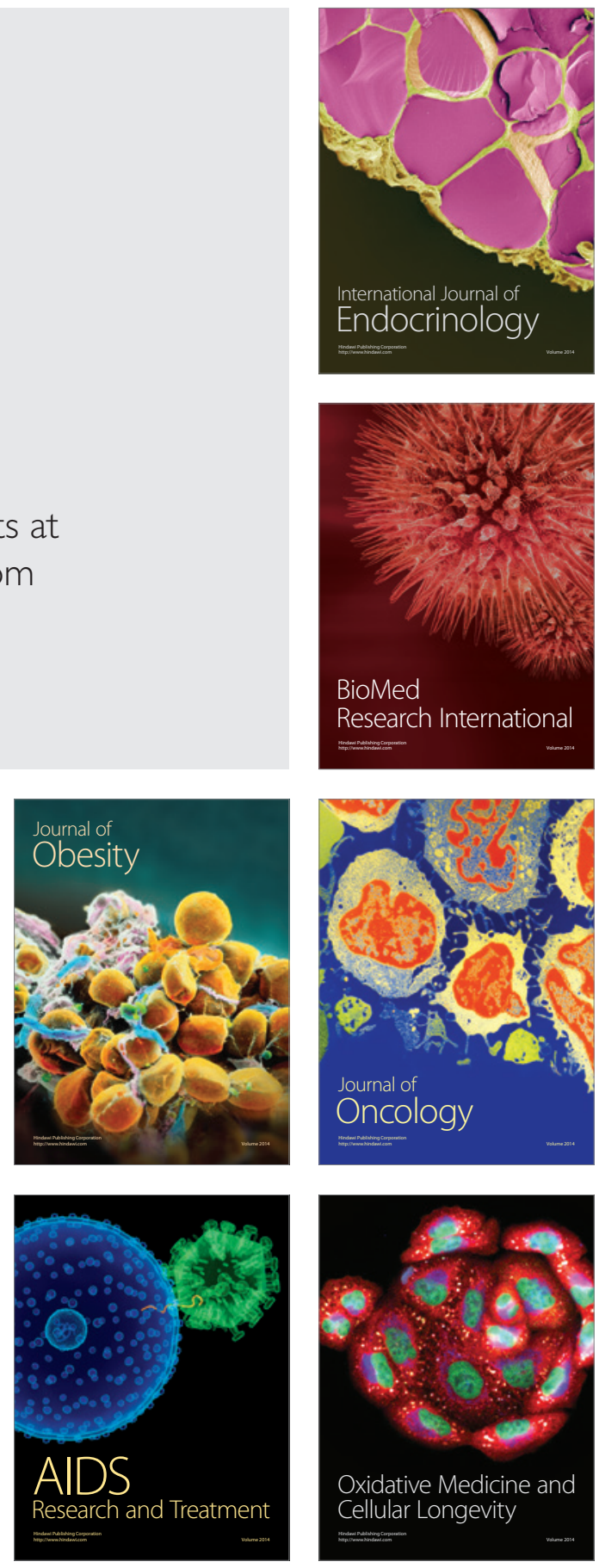